\title{
GROWTH PERFORMANCE, DIGESTIBILITY, CARCASS TRAITS AND SOME BLOOD CONSTITUENTS OF JAPANESE QUAILS AS AFFECTED BY SUPPLEMENT OF CHROMIUM IN GROWING RATIONS
}

\author{
W. Ezzat*; A.H.A. El-Koteat* and, M.S. Shoeib** \\ *Poult. Breeding Dep., Animal Production Research Institute, Dokki, Giza, Egypt. \\ **Poultry Nutrition Dep., Animal Production Res. Institute, Dokki, Giza, Egypt.
}

\section{ABSTRACT:}

The present study aimed to the effects of chromium $(\mathrm{Cr})$ supplementation with different levels on growth performance, digestibility nutrients, carcass characteristics, some blood constituents and economic efficiency of the growing Japanese quail.

A total number of 450 one-day-old Japanese quail's chicks was used divided randomly into five experimental groups. Each group was distributed by 3 replicates pens containing (30 birds in each) until 6 weeks of age. The $1^{\text {st }}$ group fed the basal experimental diet without supplementation (as control), while the other groups were fed on diets supplemented with 200, 400, 800, and1200 $\mu \mathrm{g}$ chromium $(\mathrm{Cr}) / \mathrm{kg}$ ration as chromium picolinate ( $\mathrm{Cr}$ pic.), respectively.

The results showed that the addition of chromium in the diets of growing Japanese quail resulted in an improvement $(P<0.05)$ in body weight, and weight gain of group which received $1200 \mu \mathrm{g} \mathrm{Cr} / \mathrm{kg}$ diet as compared to control one at the first three and six weeks of age. Moreover, at the same level addition of chromium in quail diets significantly $(P \leq 0.05)$ improved the feed conversion, protein efficiency ratio and efficiency of energy utilization when compared with those fed unsupplemental diet, during the experimental periods (0-3 and 0-6 weeks of age). However, the addition up to $800 \mu \mathrm{g} / \mathrm{kg}$ of $\mathrm{Cr}$ in the diets improved significantly $(P<0.05)$ the digestibility of organic matter and nitrogen free extract, while crude protein, crude fibre and ether extract digestibility were insignificantly affected. The results, also demonstrated that the abdominal fat decreased as the levels of chromium increased while, carcass percentage was increased. Serum total cholesterol, glucose were significantly $(P<0.05)$ decreased by $C r$ supplementation. On the other hand total lipid, total tri-glycerides and high density lipoprotein cholesterol (HDL $\%)$ showed the inverse trend.

The highest value of economic efficiency (EE) was obtained for quails fed on diets supplemented by $\mathrm{Cr}$ up to $800 \mu \mathrm{g} / \mathrm{kg}$.

The results from this study demonstrate that a supplementation up to $800 \mu \mathrm{g} / \mathrm{kg}$ of $\mathrm{Cr}$ in the ration improved the growth performance, digestibility, carcass characteristics and blood constituents of the growing Japanese quail. Key words: Japanese quails, growth, digestibility, chromium, blood constituents 


\section{INTRODUCTION}

Animal nutrition subcommittees have not yet made final recommendations on minimum dietary $\mathrm{Cr}$ requirements for any farm animals or poultry species. Chromium is not currently considered an essential trace element for poultry, although this micronutrient may play a nutritional and physiological role. Moreover, the NRC has recommended $300 \mu \mathrm{g} \mathrm{Cr} / \mathrm{kg}$ diet for laboratory animals (NRC, 1994). Therefore, many researchers have suggested that $\mathrm{Cr}$ should become a key ingredient in nutritional supplements, official bodies such as the National Research Council (NRC) in USA.

Most poultry diets are basically composed of plant original ingredients, which have usually low content of chromium (Giri et al., 1990). Chromium (Cr), is a trace mineral that is widely distributed throughout the body. It is involved in lipid, carbohydrate, protein and nucleic acid metabolism (Nielsen, 1994). Chromium is most associated with carbohydrate metabolism, being necessary for optimal insulin function and glucose uptake by insulin-sensitive cells (Anderson, 1985). Chromium deficiency leads to glucose intolerance and Chromium supplementation of the diets of elderly humans has resulted in improved glucose tolerance (Mertz, 1993).

Generally, chromium is accepted to be the active component in glucose tolerance factor (GTF), which increases the sensitivity of tissue receptors to insulin, resulting in increased glucose uptake by cells (Mertz, 1967and 1969)

The use of chromium has been suggested to have positive impacts on farm profitability, and many animal health benefits, including increased longevity; enhanced reproduction, improved immune response and lean broilers, growth performance, carcass, blood parameters and carcass quality (Motozono et al.,1998). Dietary chromium supplementation has been shown to positively affect growth rate and feed efficiency as obtained by Cupo and Donaldson (1987) on chickens; Lien et al., (1999) on broilers and Sahin et al., (2001) on laying hens.

Lien et al. (1999) reported that 1600 and $3200 \mu \mathrm{g} / \mathrm{Cr}$ Pic supplementation in a broiler diets increased feed intake and improved live weight gain. Kim et al. (1996) also observed that $1600 \mu \mathrm{g} / \mathrm{Cr}$ picolinate supplementation increased the weight gain and feed intake without affecting feed conversion in broilers. It has been shown that $\mathrm{Cr}$ supplementation cause significant changes in the chemical composition of animal carcasses (Lukaski, 1999). With regarded to, increasing carcass yield, abdominal fat content and decreasing (\%) in broilers has been reported for diets supplemented with Cr picolinate (Sahin et al., 2002) or Cr yeast (Hossain et al.,1998 and Debski et al.,2004)

Therefore, the aim of this study was to throw more light in the effect of chromium supplementation on growth performance, digestibility, carcass characteristics, blood constituents and economic efficiency of the growing Japanese quail chicks. 


\section{MATERIALS AND METHODS}

This study was carried out at Inshas Poultry Breeding Research Station, Animal Production Institute, Agricultural Research Center, Ministry of Agriculture, Dokki, Egypt, from $12^{\text {th }}$ February to $25^{\text {th }}$ March 2005.

A total number of 450 one-day-old Japanese quail's chicks was distributed randomly into five experimental groups. Each group was represented by 3 replicates pens containing 30 birds for each until 6 weeks of age. The birds were fed the cornsoy diet formulated to full fill the quail nutrient requirements according to NRC (1994) .Corn-soy diet was containing $23.73 \% \mathrm{CP}$ and $2900 \mathrm{Kcal} \mathrm{ME} / \mathrm{kg}$ diet. The ingredient composition and chemical analysis of the basal diet are presented in Table 1. The dietary treatment were unsupplemented diet as control diet, 200, 400, 800 , and $1200 \mu \mathrm{g}$ chromium $(\mathrm{Cr}) / \mathrm{kg}$ diet as chromium picolinate $(\mathrm{Cr}$ pic.) which (contain $12.27 \% \mathrm{Cr}$ ). All the experimental diets as well as fresh water were constantly offered ad libitum throughout the experimental period. All birds were kept in batteries under similar conditions along the experimental period.

Individual body weight was recorded at one day and then at three and six weeks of age. Feed consumption during these periods was recorded. Live body weight, weight gain, feed conversion ratio ( $\mathrm{g}$ feed / g gain), protein efficiency ratio ( $\mathrm{g}$ gain /g crude protein) and efficiency of energy utilization (ME consumed Kcal /g gain) were also calculated and recorded during the experimental periods.

Six birds from each treatment were used in digestibility trails to evaluate the nutrients digestibility of the experimental diets. Birds were housed individually in metabolic cages and fed the tested diets. During the collection period (6 days) feed intake was measured and excreta output was collected daily, oven dried ( $70 \mathrm{C}^{0}$ for 24 hrs, weighed and ground). The representative samples were used for analysis. The chemical analysis of diets and excreta for DM, EE, CP, CF and ash were conducted according to A.O.A.C. (1990). For calculating CP digestibility, the fecal protein was determined according to Ekman et al. (1949) to obtain urinary organic matter; the figure of urinary nitrogen was computed by Galal (1968) as shown in Sturkie (1965)

At six weeks of age, six birds from each treatment were randomly chosen, weighed and then slaughtered. Blood samples were collected on the time of slaughtering from each bird. Blood was collected in tubes and used for the preparation of serum samples by centrifugation at $4000 \mathrm{rpm}$ for 20 minutes and serum samples were stored at $-20^{\circ} \mathrm{C}$ pending analysis to determination the total protein (Peters, 1968), albumin, (Doumas et al., 1971), glucose (Keilin and Hartree, 1948), total lipids (Zollner and Kirsch, 1962) triglycerides (Fossati and Prencipe 1982), and cholesterol (Waston, 1960) by using available commercial kits Bio-Merieux, France. Serum globulin was calculated by the difference between serum total protein and albumin, (Sturkie, 1976).

After complete bleeding and feather removal, carcass, liver, gizzard, heart and abdominal fat were weighed and recorded as percentage of body weight.

At the end of this work, the economical efficiency of the experimental diet was calculated from the input-output analysis based upon the differences in both 
Table (1): Composition and calculated analysis of experimental corn-soy diet during periods.

\begin{tabular}{lc}
\hline Ingredients & \% \\
\hline Yellow corn & 50.53 \\
Soybean meal (44\%) & 44.00 \\
Plant oil & 2.51 \\
Bone meal & 2.27 \\
Vit \&Min premix* & 0.30 \\
NaCl & 0.25 \\
DL-methionine & 0.14 \\
\end{tabular}

\begin{tabular}{lc}
\hline Total & $\mathbf{1 0 0}$ \\
\hline Determined analysis *** & \\
Dry matter (DM) & 90.20 \\
Organic matter (OM) & 83.02 \\
Crude protein (CP) & 23.73 \\
Ether extract & 4.65 \\
Crude fiber & 4.25 \\
N-Free extract & 50.39 \\
Ash & 7.18 \\
Calculated analysis** & \\
ME (Kcal/kg) & 2900 \\
Ca & 0.81 \\
P. Avail. & 0.43 \\
Lys & 1.31 \\
Meth & 0.50 \\
Cystine & 0.38 \\
Meth +Cys & 0.88
\end{tabular}

*Vitamins and minerals premix at $0.3 \%$ of the diet supplies the following per $\mathrm{kg}$ of the diet: Vit. A:12000IU; Vit D 2000 IU; Vit E: 40 mg; Vit K3 4 mg; Vit B1 3 mg; Vit B2 6 mg; Vit B6 4 mg; Vit B12 $.03 \mathrm{mg}$; Niacin $30 \mathrm{mg}$; Ca. Pantothenate $12 \mathrm{mg}$ Folic acid $1.5 \mathrm{mg}$; Biotin $.08 \mathrm{mg}$; Choline chloride 50\% 700 mg; Mn 10 mg; Cu 10 mg; Fe 40 mg; Zn 70 mg; Se 0.2 mg; I 1.5 mg; Co 0.25 mg; CaCo3 AD $3000 \mathrm{mg}$. $\quad * *$ According to NRC (1994).

growth rate and feeding cost as described by Bayoumi (1980).

Data were statistically analyzed using SAS® software computer program (SAS, 1998) and the significant differences between means were detected according to Duncan (1955).

\section{RESULTS AND DISCUSSION}

\section{Growth performance:}

\subsection{Body weight and weight gain}

The impacts of supplementing different levels of chromium on body weight and weight gain for Japanese quail chicks are shown in Table 2. These results indicated that supplementing diets with chromium was significant increases $(\mathrm{P}<0.05$ 
and 0.01) in body weight and weight gain at different ages studies of quails which received $1200 \mu \mathrm{g} \mathrm{Cr} / \mathrm{kg}$ diet as compared to control group at three and six weeks of age, receptively. Similar to those results by Mooney and Cromwell, (1997) and Sahin et al. (2002) who reported that increase supplemental Cr $(200,400,800$ or $1200 \mu \mathrm{g} \mathrm{Cr}$ picolinte) results in an increase body weight in broilers. Also, Ibrahim (2004) indicated that supplementing $\mathrm{Cr}$ at levels of $10,20,30,40$ and $50 \mathrm{mg} \mathrm{Cr} / \mathrm{kg}$ diet increased significantly final body weight. These results indicated that no significant differences $(\mathrm{P}<0.05)$ in body weight and weight gain were observed groups received in 200, 400, and 800, $\mu \mathrm{g} \mathrm{Cr} / \mathrm{kg}$ diet compared to control group. These results supported the findings of Uyank et al (2005) who found that 20,40,60,80, or 100 $\mathrm{mg} / \mathrm{kg} \mathrm{Cr}$ supplementation to quail diet had no effect on body weight. The observed increase in growth performance may be due to supplementing $\mathrm{Cr}$ confirmed the beneficial effects on physiological functions required for performance (Lukaski, 1996; Sands and Smith, 1999 and El- Kaiaty et al., 2005) on broiler chicks. Also, Cr is involved in protein metabolism (NRC, 1997) and is thought to have a role in nucleic acid metabolism because it increased amino acid incorporation into liver protein in vitro as observed by Weser and Koolman (1969). The present results suggested that $\mathrm{Cr}$ supplementation up to level of $400 \mu \mathrm{g} / \mathrm{kg}$ diet tended to be improving body weight, and weight gain however, $1200 \mu \mathrm{g} \mathrm{Cr} / \mathrm{kg}$ diet gave the highest body weight and weight gain could be recommended as a suitable supplemental level for Japanese quail chick's diets. These results are in agreement with those of Motozono et al. (1998) and Uyank et al. (2005) who reported that supplementation of the diet quail had no effect on body weight gain.

\subsection{Feed intake and feed conversion ratio:}

Table 2. indicated that the feed intake of the quail group fed diet supplemented with chromium at different levels was significantly $(\mathrm{P} \leq 0.05)$ lower during the period from 0-3 and 0-6 weeks of age as compared with control group. However, the differences among them at 0-6 weeks were not significant effect of $1200 \mu \mathrm{g} \mathrm{Cr} / \mathrm{kg}$ when as compared with the control group. These results obtained are in agreement with those of Sahin et al. (2002) who reported that increase supplemental $\mathrm{Cr}$ $(200,400,800$ or $1200 \mu \mathrm{g} \mathrm{Cr})$ results in an increase feed intake and feed efficiency in broilers reared under heat stress. While, Uyanik et al. (2002) demonstrated that 20 $\mathrm{mg} / \mathrm{kg}$ supplemental $\mathrm{Cr}$ in broiler diets resulted in $18.57 \%$ reduction in feed consumption. Obtained results showed that adding chromium in quail diets improved feed conversion ratio, this effect was significant $(\mathrm{P} \leq 0.05)$ at early ages $(0-3$ and $0-6$ weeks of age) but the improvement start to occur non-significant at late ages. Reports indicated that $\mathrm{Cr}$ supplementation to broiler diets significantly improved feed conversion (Sahin et al., 2002 ; Uyanik et al., 2002; Ibrahim, 2004; and El-Kaiaty et al., 2005) who reported that supplemental $\mathrm{Cr}$ in broiler diets $(1.5$ and $2.5 \mathrm{mg} \mathrm{Cr} / \mathrm{kg})$ improved the feed conversion from 1-6 weeks of age. 


\subsection{Protein efficiency ratio and efficiency of energy utilization:}

The results obtained in Table 2 indicated that, the addition of chromium in quail diets at different levels significantly $(\mathrm{P} \leq 0.05)$ improved the protein efficiency ratio and efficiency of energy utilization compared with those fed unsupplemented diet at 0-3 and 0-6 weeks of age. On the other hand during 3-6 weeks of age the treatments were insignificantly improved than the control ones. These results may be due to the most important function of $\mathrm{Cr}$ is probably its role in the Carbohydrates and Lipids metabolism (Guerra et al., 2002), protein and Nucleic acids (Anderson and Kozlovsky, 1985) in many animals species.

\section{Digestibility coefficients:}

The effects of dietary supplementation on the digestibility coefficients of nutrients are summarized in Table 3. Results indicated that using the optimum level of chromium at $1200 \mu \mathrm{g} C \mathrm{r}$ improved significantly $(\mathrm{P}<0.05)$ the digestibility value of organic matter, nitrogen free extract while the digestibility coefficients of the other nutrients were insignificantly affected. These resulted are in agreement with those of Sahin et al. (2001) who reported that digestibility of dry matter, organic matter, ether extract, crude protein, crude fibre and nitrogen free extract increased linearly $(\mathrm{P}<$ $0.01)$ and quadratically $(\mathrm{P}<0.01)$ by supplemental dietary $\mathrm{Cr}$ picolinate in laying hens under cold conditions $(\mathrm{P}<0.01)$. Also, they added that supplemental dietary $\mathrm{Cr}$ picolinate increased yield and nutrient digestibility in laying hens at low temperature.

\section{Serum blood constituents}

Supplementary $\mathrm{Cr}$ effects on serum total protein, albumin, globulin, total lipids, total cholesterol, high density lipoprotein (HDLC) and low density lipoprotein cholesterol (LDLC) values, glucose and tri- glycerdes are presented in Table 4.

Results of serum chemistry profile indicated that $\mathrm{Cr}$ supplementation had no significant effect on serum total protein, albumin and globulin in quail chicks at six of age. These results are in agreement with Mohamed and Afifi (2001) who reported that serum total protein and albumin did not affect by $\mathrm{Cr}$ concentration. El-Kaiaty et al (2005) reported that supplemental $\mathrm{Cr}$ in broiler diets (1.5 and $2.5 \mathrm{mg} \mathrm{Cr} / \mathrm{kg}$ ) did not effect on total protein, albumin and globulin at different ages.

With regard to the value of total lipids and total tri-glycerides, were significantly $(\mathrm{P}<0.05$ and $\mathrm{P}<0.01)$, respectively increased by increasing inclusion of chromium in the diets. These results agree with Ibrahim (2004) who observed that total lipids and total tri-glycerides in groups received the $\mathrm{Cr}$ supplemented diet (20, 30 , 40, or $50 \mathrm{mg} \mathrm{Cr} / \mathrm{kg}$ ) improved by increasing level of $\mathrm{Cr}$ as compared to control group. Kim et al. (1995) found that serum tri-glycerides were affected by $\mathrm{Cr}$ supplementation. However, cholesterol, LDLC value and glucose significantly $(\mathrm{P}<$ 0.01 ) decreased as chromium levels increased in the experimental diets (Table 5) .While, HDLC value significantly $(\mathrm{P}<0.05)$ increased by chromium levels increased in the experimental diets. These results attributed to those Lin et al., (1999) who showed that the supplementation of organic Cr could effectively decrease serum total cholesterol in laying hens and increase serum HDLC value as compared with control group. Lien et al., (1999) reported that dietary supplementation with $\mathrm{Cr}$ at levels of 
Table (3): Digestibility coefficients (\%) of Japanese quail at six weeks of age as affected by supplemented diets with different levels of chromium picolinate.

\begin{tabular}{|c|c|c|c|c|c|c|}
\hline \multirow{2}{*}{$\begin{array}{l}\text { Digestibility } \\
\text { coefficients }\end{array}$} & \multicolumn{5}{|c|}{ Chromium picolinate ( $\mu \mathrm{g} \mathrm{Cr} / \mathrm{kg}$ ration) } & \multirow[b]{2}{*}{ Sig. } \\
\hline & $\mathbf{0}$ & 200 & 400 & 800 & 1200 & \\
\hline Crude protein & $\begin{array}{l}84.760 \\
\pm 0.680\end{array}$ & $\begin{array}{l}84.890 \\
\pm 0.723\end{array}$ & $\begin{array}{l}84.900 \\
\pm 0.773\end{array}$ & $\begin{array}{l}85.005 \\
\pm 0.904\end{array}$ & $\begin{array}{l}85.220 \\
\pm 0.890\end{array}$ & NS \\
\hline Ether extract & $\begin{array}{l}82.897 \\
\pm 0.741\end{array}$ & $\begin{array}{l}83.475 \\
\pm 0.977\end{array}$ & $\begin{array}{l}83.219 \\
\pm 0.766\end{array}$ & $\begin{array}{l}83.108 \\
\pm 0.825\end{array}$ & $\begin{array}{l}83.077 \\
\pm 0.792\end{array}$ & NS \\
\hline Crude fiber & $\begin{array}{l}23.593 \\
\pm 0.601\end{array}$ & $\begin{array}{l}23.832 \\
\pm 0.634\end{array}$ & $\begin{array}{l}23.298 \\
\pm 0.685\end{array}$ & $\begin{array}{l}24.159 \\
\pm 0.559\end{array}$ & $\begin{array}{l}24.616 \\
\pm 0.632\end{array}$ & NS \\
\hline Organic matter & $\begin{array}{l}76.555 \\
\pm 0.670^{\mathrm{c}}\end{array}$ & $\begin{array}{l}77.297 \\
\pm 0.533 \text { bc }\end{array}$ & $\begin{array}{l}77.773 \\
\pm 0.412 \text { ab c }\end{array}$ & $\begin{array}{l}78.305 \\
\pm 0.434\end{array}$ & $\begin{array}{l}78.967 \\
\pm 0.430\end{array}$ & $*$ \\
\hline $\begin{array}{l}\text { Nitrogen free } \\
\text { extract }\end{array}$ & $\begin{array}{l}82.976 \\
\pm 0.422^{\mathrm{c}}\end{array}$ & $\begin{array}{l}83.347 \\
\pm 0.463^{c}\end{array}$ & $\begin{array}{l}83.908 \\
\pm 0.358 \mathrm{bc}\end{array}$ & $\begin{array}{l}84.579 \\
\pm 0.327^{\text {ab }}\end{array}$ & $\begin{array}{l}85.399 \\
\pm 0.395^{\text {a }}\end{array}$ & $*$ \\
\hline
\end{tabular}

a, b, c Means in the same row with different superscripts are significantly $(\mathrm{P}<0.05)$.

NS: Not significant, $\quad * \mathrm{P}<0.05, \quad * * \mathrm{P}<0.01$. Sig. : Significance

1600 and $3200 \mu \mathrm{g} / \mathrm{kg}$ significantly $(\mathrm{P}<0.05)$ decreased serum glucose, cholesterol, LDLC value, while the same level significantly $(\mathrm{P}<0.05)$ increased serum HDLC in broiler. Sahin et al., (2002), Uyanik et al. (2002) and Ibrahium (2004) who reported that increased supplemental $\mathrm{Cr}$ in broiler diet decrease cholesterol and glucose concentration. Chromium is generally accepted as the active component in the glucose tolerance factor (GTF), which increases the sensitivity of tissue receptors to insulin, resulting in increased glucose uptake by cells. Research suggests $\mathrm{Cr}$ involvement in carbohydrate metabolism including glucose uptake, glucose utilization for lipogenisis, and glycogen formation (Anderson et al., 1991). It was hypothesized that increased glucose uptake should increase oxidation of glucose, which would be otherwise converted to fatty acids and stored as triglycerides in adipose tissues.

\section{Carcass characteristics:}

Data presented in Table 5 showed no significant differences between the treated groups received $\mathrm{Cr}$ supplemented diet and control group of both heart, liver, gizzard, giblets and dressing percentages. While, carcass percentages were significantly increased $(\mathrm{P}<0.05)$ in groups received 800 , and $1200 \mu \mathrm{g}$ chromium as compared with the control group. Moreover, $\mathrm{Cr}$ supplementation to quail diets significantly $(\mathrm{P}<0.05)$ decreased abdominal fat percentages. However, $\mathrm{Cr}$ supplementation significantly $(\mathrm{P}<0.05)$ decreased abdominal fat percentages (Choct, 1999, Sahin et al., 2002 and Ibrahim, 2004). Moreover, Uyank et al. (2005) reported that chromium supplementation in quail diets significantly decreased $(\mathrm{P}<0.05)$ abdominal fat percentages compared with the control group. Toghyani et al. (2006) indicated that $\mathrm{Cr}$ supplementation $(500,1000$ or $1500 \mathrm{ppb})$ increased carcass yield and decreased abdominal fat. 


\section{Economic efficiency (EE)}

The economic evaluation results of this study are summarized in Table 6 . Addition of $\mathrm{Cr}$ in the diets at levels of 200, 400, 800, and $1200 \mu \mathrm{g} / \mathrm{kg}$ diet significantly $(\mathrm{P}<0.05)$ increased $\mathrm{EE} \quad(\%)$ compared to control one. These improvements in EE were 5.69, 11.52, 11.66 and $11.95 \%$ than the control value,

Table (6): Input-output analysis and Economic efficiency of Japanese quail as affected by different levels of supplemented with different levels chromium picolinate from 0-6 weeks of age.

\begin{tabular}{|c|c|c|c|c|c|c|}
\hline \multirow[t]{2}{*}{ Items } & \multicolumn{5}{|c|}{ Chromium picolinate ( $\mu \mathrm{g} \mathrm{Cr} / \mathrm{kg}$ ration) } & \multirow[b]{2}{*}{ Sign. } \\
\hline & $\mathbf{0}$ & 200 & 400 & 800 & 1200 & \\
\hline Body weight gain $(\mathrm{kg})$ & $\begin{array}{l}0.188 \pm \\
0.003^{b}\end{array}$ & $\begin{array}{l}0.188 \pm \\
0.002^{\mathrm{b}}\end{array}$ & $\begin{array}{l}0.191 \pm \\
0.001^{\mathrm{b}}\end{array}$ & $\begin{array}{l}0.191 \pm \\
0.001^{\mathrm{b}}\end{array}$ & $\begin{array}{l}0.198 \pm \\
0.002^{\mathrm{a}}\end{array}$ & * \\
\hline Price/ kg body weight & 15 & 15 & 15 & 15 & 15 & NS \\
\hline $\begin{array}{l}\text { Total revenue/ chick } \\
\text { (LE) }\end{array}$ & $\begin{array}{l}2.820 \pm \\
0.038^{b}\end{array}$ & $\begin{array}{l}2.820 \\
\pm 0.027^{b}\end{array}$ & $\begin{array}{l}2.865 \pm \\
0.009^{b}\end{array}$ & $\begin{array}{l}2.865 \pm \\
0.018^{b}\end{array}$ & $\begin{array}{l}2.970 \pm \\
0.027^{\mathrm{a}}\end{array}$ & * \\
\hline Total feed intake (kg) & $\begin{array}{l}0.700 \pm \\
0.002^{\mathrm{a}}\end{array}$ & $\begin{array}{l}0.675 \\
\pm 0.002^{b}\end{array}$ & $\begin{array}{l}0.666 \\
\pm 0.003^{b}\end{array}$ & $\begin{array}{l}0.663 \\
\pm 0.004^{b}\end{array}$ & $\begin{array}{c}0.695 \pm \\
0.009^{\mathrm{a}}\end{array}$ & ** \\
\hline Price/kg feed (LE) & 1.652 & 1.656 & 1.660 & 1.667 & 1.672 & NS \\
\hline $\begin{array}{l}\text { Total feed cost/ chick } \\
\text { (LE) }\end{array}$ & $\begin{array}{l}1.156 \pm \\
0.003^{\mathrm{a}}\end{array}$ & $\begin{array}{l}1.118 \\
\pm 0.003\end{array}$ & $\begin{array}{l}1.106 \\
\pm 0.004^{b}\end{array}$ & $\begin{array}{l}1.105 \\
\pm 0.007^{b}\end{array}$ & $\begin{array}{l}1.162 \pm \\
0.014^{\mathrm{a}}\end{array}$ & $*$ \\
\hline Fixed cost/ chick (LE) & 0.50 & 0.50 & 0.50 & 0.50 & 0.50 & NS \\
\hline Total cost chick (LE) & $\begin{array}{l}1.656 \pm \\
0.003^{\mathrm{a}}\end{array}$ & $\begin{array}{l}1.618 \\
\pm 0.003^{b}\end{array}$ & $\begin{array}{l}1.606 \\
\pm 0.004^{b}\end{array}$ & $\begin{array}{l}1.605 \\
\pm 0.007^{\mathrm{b}}\end{array}$ & $\begin{array}{l}1.662 \pm \\
0.014^{\mathrm{a}}\end{array}$ & $*$ \\
\hline Net Revenue (LE) & $\begin{array}{l}1.164 \pm \\
0.038^{\mathrm{c}}\end{array}$ & $\begin{array}{l}1.202 \\
\pm 0.024^{\mathrm{bc}}\end{array}$ & $\begin{array}{l}1.259 \\
\pm 0.005^{a b}\end{array}$ & $\begin{array}{l}1.260 \\
\pm 0.018^{a b}\end{array}$ & $\begin{array}{r}1.308 \pm \\
0.024^{\mathrm{a}}\end{array}$ & $*$ \\
\hline Economic efficiency & $\begin{array}{l}0.703 \pm \\
0.023^{\mathrm{c}}\end{array}$ & $\begin{array}{l}0.743 \pm \\
0.014^{b}\end{array}$ & $\begin{array}{l}0.784 \pm \\
0.001^{\mathrm{a}}\end{array}$ & $\begin{array}{c}0.785 \pm \\
0.013^{\mathrm{a}}\end{array}$ & $\begin{array}{l}0.787 \pm \\
0.017^{\mathrm{a}}\end{array}$ & * \\
\hline $\begin{array}{l}\text { Relative economic } \\
\text { efficiency }\end{array}$ & 100.00 & 105.690 & 111.522 & 111.664 & 111.949 & \\
\hline
\end{tabular}

a, b, c Means in the same row with different superscripts are significantly $(\mathrm{P}<0.05)$.

NS: Not significant, $\quad * \mathrm{P}<0.05, \quad * * \mathrm{P}<0.01$. Sign.: Significance 
respectively. These results are in agreement with Ibrahim (2004) who reported that the addition of $\mathrm{Cr}$ to diet at levels of 10, 20,30, and $40 \mathrm{mg} / \mathrm{kg}$ improved EE compared with control group in broiler.

Conclusion, the results of the current study suggest that supplementation of chromium in quail diets up to $800 \mu \mathrm{g} \mathrm{Cr} / \mathrm{kg}$ diet caused to improve growth performance and economic efficiency values. There are other positive effects, including reduced abdominal fat and increased dressing \%. Chromium may be one of the most important trace minerals in broiler feed formulation in the new millennium.

\section{REFERENCES}

A.O.A.C. (1990). Association of Official Analytical Chemists. Official Methods of Analysis, 15th Edition, Washington, USA.

Anderson, R.A. (1985). Chromium supplemental: Effects on glucose tolerance and lipid. InH. Bostrom and N. Ljungstedt (Ed.) Trace Elements in Health and Disease. Almqvist \& Wiksell International, Stockholm, Sweden.

Anderson, R.A. and Kozlovsky, A.S. (1985). Chromium intakes absorption and excretion of subjects consuming self-selected diets. American J. of Clinical Nutrition. 41: 1171-1183.

Anderson, R.A.; Polansky, M.P.; Bryden, N.A.; and Canary, J.J. (1991). Supplemental chromium effects on glucose, insulin, glucagons, and urinary chromium losses in subjects consuming controlled low chromium diets. Am. J. Clin., Nutr., 54: 909-916.

Anderson, R.A. (1997). Chromium as an essential nutrient for humans .Regul. Toxicol. Pharmacol., 26:535-541.

Bayoumi, S.D. (1980). Effect of different rations on egg production for breeding hens M.Sc. Thesis, Fac. of Agric. Kafr El- Sheikh. Tanta Univ.

Choct, M. (1999). Increasing efficiency of lean tissue deposition in broiler chickens. Rural Industries Research and Development Corporation Project UNE-54A, University of New England, Amidale, NSW, Australia.

Cupo, M.A.; and Donaldson, W.E. (1987). Chromium and vanadium effects on glucose metabolism and lipid synthesis in the chick. Poult. Sci., 66:120-128.

Debski, B.; Zalewski, W.; Gralak, M. A.; and Kosla, T. (2004). Chromium yeast supplementation of broiler in an industrial farming system. J. Trace Ele. Med., Biol., 18: 47-51.

Doumas, B.T.; Waston, W.A.; and Biggs, H.S. (1971). Albumin standards and measurement of serum albumin with bromocresol green. Clin. Chem.Acta., 31:87-96.

Duncan, D.B. (1955). Multiple range and multiple "F" test. Biometrics, 11: 1-42.

Ekman, P.; Emanueleson, H. and Fransson, A. (1949). Investigations concerning the digestibility of protein in poultry. Annals Royal Agric. College of Seweden, 16: 749-777. 
El-Kaiaty, A.M.; Fatma, R.M.; Eman, M. A.; and Abeer, A.M. E. (2005). Beneficial impact of organic chromium supplementation of broiler diets on growth performance, some blood constituents and immunological status. Egyptian J.Nutr. and Feeds., 8(1) :737-759.

Fossati, P.; and Prencipe, L. (1982). Rapid enzymatic colorimetric method for determination of triglycerides in serum. Clin. Chem. J., 28:2077-2082.

Galal, A. Gh, (1968). A study of some carbohydrate components of poultry feeds and their relation to the feeding value with reference to lignin fraction. Ph.D. Thesis, Fac Agric., Cairo Univ.

Giri, J.; Usha, K.; and Sunita, T. (1990). Evaluation of the selenium and chromium content of plants foods. Plant Foods Hum. Nutr., 40: 49-59.

Guerra, M.G.; Renzulli, C.; Antelli, A.; Pozzetti, L.; Poolini, M. and Speroni, E. (2002). Effects of trivalent chromium on hepatic CYP-linked monooxygenases in the laying hens. Journal of Applied Toxicology. 22(3):161- 168

Hossain, S.M.; Barreto, S.L.; and Silva, G.G., (1998). Growth performance and carcass composition of broiler fed supplemental chromium from chromium yeast. J. Anim. Feed. Sci. Tech., 71: 217-228.

Ibrahim, K. A. (2004). Effects of dietary chromium supplementation on growth performance, carcass characteristics and some blood parameters of broilers. Egyptian, Poul. Sci., 25: 167-185.

Keilin D. and Hartree, E.F. (1948). Glucose oxidase methodology. Biochem. J., 42: 230.

Kim, S.W.; Han, I.K.; Choi, Y.J; Kim, Y.H.; Shin, I.S.; and Chae, B.J. (1995). Effect of chromium picolinate on growth performance, carcass composition, and serum traits of broilers fed dietary defferent levels of crude protein. Asian J. Anim. Sci., 8: 463-470.

Kim, J.D.; Han, I.K.; Choi, Y.J.; Shin, I.S.; Chae, B.J.; and Kang, T.H. (1996). Effects of dietary excessive chromium picolinate on growth performance, carcass composition, and serum traits of broilers fed diets varying in protein and lysine. Asian J. Anim. Sci., 9: 455-462.

Kroliczewska,-B; Zawadzki,-W; Dobrzanski,-Z; and Kaczmarek-Oliwa,-A. (2004). Changes in selected serum parameters of broiler chicken fed supplemental chromium. Journal of Animal Physiology and AnimalNutrition., 88: 393-400.

Lien,T.F.; Horng,Y.M.; and Yang,K.H.(1999). Performance, serum characteristics, carcase traits and lipid metabolism of broilers as affected by supplement of chromium picolinate. British-Poultry-Science., 40: 357-363.

Lin, X. L.; Lin, F.P.; Lin,X.L.; and Lin, F.P. (1999). Effects of organic chromium on the production performance and yolk cholesterol of laying hens. Journal-of- Fujian-Agricultural-University., 28: 483-48.

Lukaski, H.C. (1996). Magnesium, zinc and chromium nutrition and physical activity. Can. J. Appl. Nutr., 63: $954-965$. 
Lukaski, H.C. (1999). Chromium as supplement. Annual Rev. Nutr., 19: 279-302.

McCarty, M.F., (1991). The case for supplemental chromium and a survey of clinical studies with chromium picolinate. J. Of Appl. Nutr., 43: 58-66.

Mertz, W. (1967). Biological role of chromium. Physiol. Fed. Proc., 26: 186-193.

Mertz, W. (1969). Chromium occurrence and function in biological systems. Physiol. Rev., 49: 163-239.

Mertz, W. (1993). Chromium in human nutrition: A review. J. Nutr., 123:626. National Academy Press, Washington. D.C.

Mohamed, F.F.; and Afifi . M. (2001). Role of inorganic chromium in modulating performance and immunity in broiler. Vet. Med. J. Giza, 49(1): 147-162.

Mooney, K.W.; and Cromwell G.L. (1997). Efficacy of chromium picolinate and chromium chloride as potential, carcass modifiers in swine. J. Animal Sci., 75:2661-2671.

Motozono, Y.; Hatano, K.; Sugawara, N.; and Ishibashi, T.(1998). Effects of dietary chromium picolinate on growth, carcass quality and serum lipids of female broilers. Animal-Science-and-Technology., 69: S659-665.

NRC (1994). National Research Council Nutrient Requirements of Poultry. 9 th Rev. Ed.National Academy Press, Washington. D.C.

NRC (1997). National Research Council. The role of chromium in animal nutrition Committee of Animal Nutrition. National Academy Press, 2101 Constitution Avenue, N.W. Washington, D.C. 20418.

Nielsen, F. H. 1994. Chromium. In: M. E. Shils, J. A. Olson and M. Shike (Eds.) Modern Nutrition in Health and Disease. ( $8^{\text {th }}$ Ed.). Lea \& Febiger, Philadelphia, PA.

Peters, T. (1968). Determination of total protein in serum. Clinical Chemistry, 14:147.

Sahin, K.; Ertas, O.N.; Guler, T.; and Ciftci, M.(2001). Effects of supplemented dietary chromium on yield nutrient digestibility of laying hens under low temperature. Turk Veterinnerlik-ve. Hayvanclk Dergisi. ,25:823-830.

Sahin, K.; Sahin, N.; Onderci, M.; Gursu, F.; and Cikim, G. (2002). Optimal dietary concentration of chromium for alleviating the effect of heat stress on growth, carcass qualities, and some serum metabolites of broiler chickens. Biol. Trace Elem. Res., 89:53-64.

Sahn, N.; Sahn, K.; Onderc, M; Gursu, M.F.;Ckm, G.; Vijaya,J.; and Kucuk, J. (2005). Chromium picolinate, rather than biotin, alleviates performance and metabolic parameters in heat-stressed quail. British poultry Sci.,46: 457-463.

Sands,J.S.; and Smith, M.O. (1999). Broilers in heat stress conditions: effects of dietary manganese proteinate or chromium picolinate supplementation. Journal of Applied Poultry Research. , 3, 280-287.

SAS (1998). SAS User's Guide: Statistical Analysis System Institute, Inc., Cary, N.C. USA.

Sturkie., P. D. (1965). "Avian Physiology" $2^{\text {nd }}$ ed. Bailliere Tindall and Casselly, London. 
Sturkie, P.D. (1976). Avian Physiology 3rd Ed. Springer Virlog. N. Y. Heidelberg, Berlin.

Toghyani, M.; Shivazad, M.; Gheisari, A.A. and Zarkesh, S.H. (2006). Performance, carcass traits and hematological parameters of heat- stressed broiler chicks in response to dietary levels of chromium picolinate. International J. of Poul. Sci., 5(1): 65-69.

Uyanik, F.; Atasever,A.; Ozdamar, S. and Aydin, F. (2002). Effects of dietary chromium chloride supplementation on performance, some serum parameter, and immune response in broilers . Boil. Trace Elme. Res., 90(1-3): 99-115.

Uyank, F; Eren, M; Guclu,B.K. and Sahin,N. (2005). Effects of dietary chromium supplementation on performance, carcass traits, serum metabolites, and tissue chromium levels of Japanese quails. Biological- Trace- ElementResearch.,. 103:187-197.

Waston, D. (1960). Determination of total cholesterol . Clin. Chem. Acta, 5: 657.

Weser, U. and Koolman, U.J. (1969). Untersuchungen zur protein biosynthese in Rattenieber zellerkernen.Hoppe Seyler's Z. Physiol. Chem., 350:1273-1278.

Zollner, N.; and Kirsch, K. (1962). Determination of total lipids in serum Ges. Exp. Med., 135:545. 


\title{
الأداء الإنتاجي ومعاملات الهضم وصفات الأبيحة ويعض مكونات الام للسمان الياباني وتأثره بإضافة الكرميوم في علائق النمو
}

\author{
*** وحيد عزت * عبد الهادي حسن عبد القادر القطيط*- محمد صلاح شعيب \\ * قسم تربية الدو اجن - معهد بحوث الإنتاج الحيو اني- مركز البحوث الزراعية- الجيزة - مصر

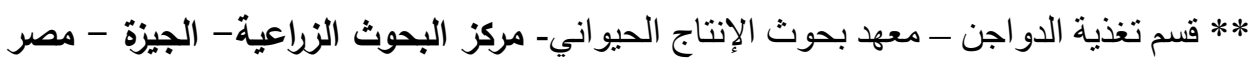

أجريت هذه الدراسة لمعرفة نأثير إضافة المستويات المختلفة من الكرميوم (بيكلونات الكرميوم) علي أداء النمو والهضم وبعض صفات الذبيحة ومكونات الدم للسمان الياباني النامي. استخدم عدد • ؛ـ كتكوت سمان عمر يوم وقسمت عشوائيا إلى 0 مجاميع تجريبية كل مجموعة بها r مكررات بكل مكررة • r طائر واستمرت التجربة

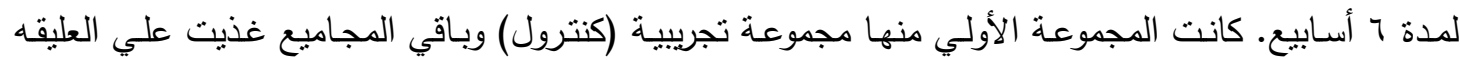

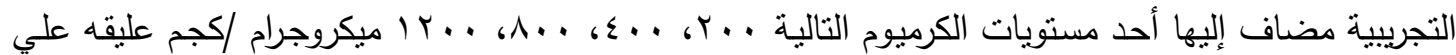
التوالي. وكانت أهم نتائج التجربـة ما يلي: أدي إضـافة الكرميوم لعلائق السمان أي زيادة معنوي (عند مستوي

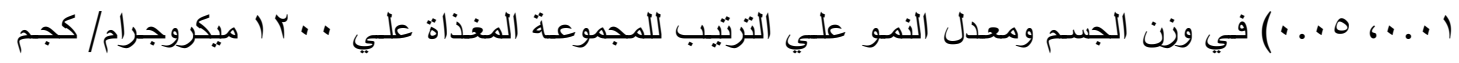

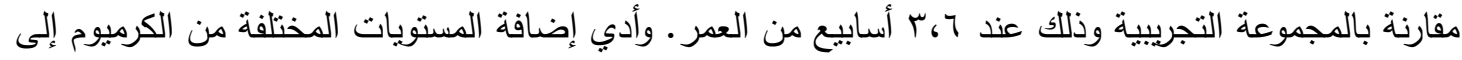

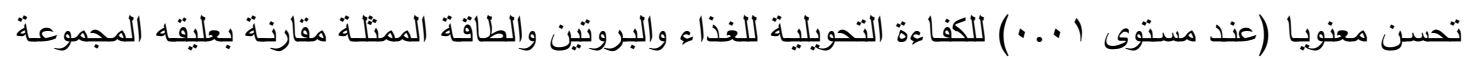

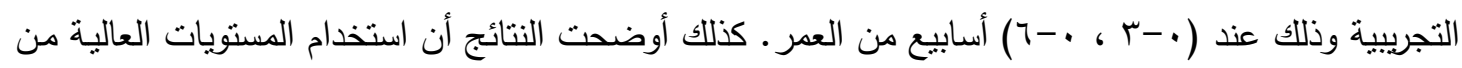

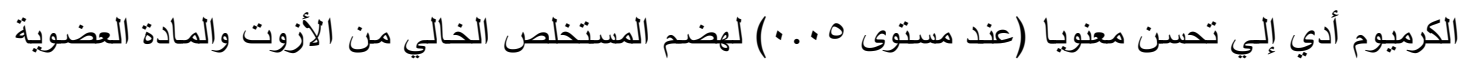
بينما لم يتأثز معنويا هضم البروتين الخام والألياف والدهن. وكذللك أوضحت النتائج نقصا معنويا لدهن البطن

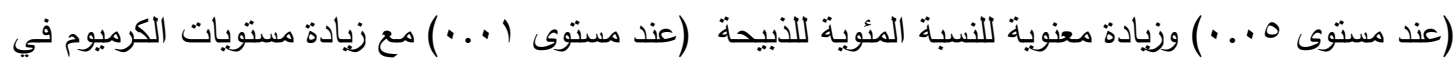

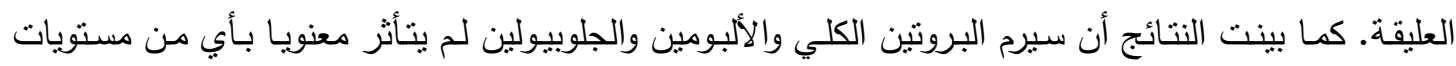

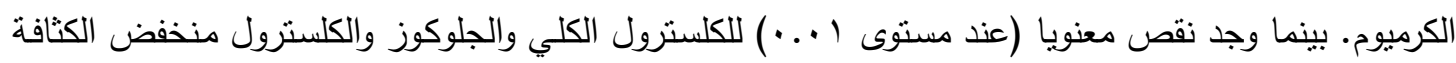

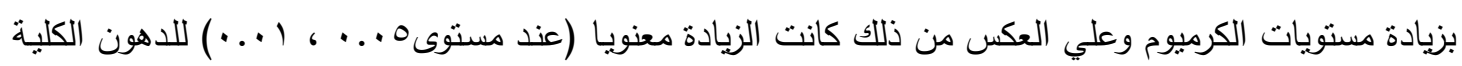
والجلسريدات الثلاثية والكلسترول عالي الكثافة بزيادة المستويات المختلفة من الكرميوم.

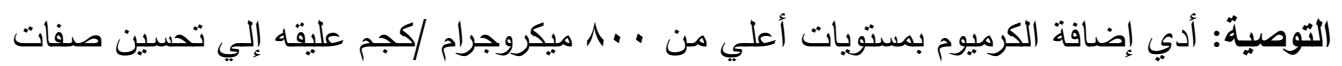
معدل أداء النمو والكفاءة الاقتصادية للسمان في الفترة من عمر يوم حتى 1 أسابيع. 